\title{
INNOVATION, TERRITORY AND INDUSTRIAL DEVELOPMENT IN PORTUGAL ${ }^{1}$
}

\author{
MARIA LUCINDA FONSECA ${ }^{2}$ \\ JORGE GASPAR $^{3}$ \\ MÁRIO VALE ${ }^{4}$
}

\begin{abstract}
Innovation holds an important role in the economic development process. The competitive potential of national and regional economies is based on the ability to manage the changing technological process. Economic competition does no longer exclusively depend on the factor costs, which vary geographicaly, because technology can now eliminate the territory disadvantages. Productivity is the crucial element in the competitive capacity of any economy. Productivity, as can easily be proved, is deeply dependent on technological development; this is only possible if there is constant innovation.

This paper starts with a brief discussion on the theoretical issues regarding innovation in relation to regional economies. In the second section the Portuguese R\&D system is analised in terms of finance and human resources. Particular attention is paid to the entrepreneurial R\&D effort, namely in manufacturing activity. Finally, some limitations of the innovation policy in the EU are pointed out, together with its consequences for the least favoured regions.
\end{abstract}

Key-words: innovation, R\&D, manufacturing activity, innovation policy

Resumo - INOVAÇão, TERRITÓRIO E DESENVOLVIMENTO INDUSTRIAL EM PORTUGAL - A inovação detém um papel relevante no processo de desenvolvimento económico, pois o potencial competitivo das economias nacionais e regionais baseia-se cada vez mais na gestão do processo de mudança tecnológica. A competição empresarial não se baseia exclusivamente no custo dos factores, que apresentam diferenciações geográficas, em virtude da tecnologia permitir eliminar ou atenuar as desvantagens de territórios com menores recursos. A chave da competitividade parece residir no nível de produtividade das empresas, que se encontra associada à capacidade de inovação, tanto nos domínios da produção como da gestão. Neste artigo discutem-se princípios teóricos da inovação no âmbito das economias regionais. Em seguida, analisa-se a dotação financeira e em recursos humanos do sistema de I\&D em Portugal, prestando-se especial atenção ao esforço em I\&D das empresas industriais. Finalmente, apontam-se algumas limitações à política de inovação na UE e as suas consequências para as regiões menos favorecidas.

Palavras-chave: inovação, I\&D, actividade industrial, políticas de inovação

\section{INTRODUCTION}

Innovation holds an important role in the economic development process. The competitive potential of national and regional economies is based on the ability to manage the changing process.

\footnotetext{
1 This article is based on a paper presented in the EUNIT Seminar, Paris 18 and 19 May, 1995. It builds on research supported by JNICT, PCSH/C/GEO/715/93.

${ }^{2}$ Professora Associada da Faculdade de Letras da Universidade de Lisboa.

${ }^{3}$ Professor Catedrático da Faculdade de Letras da Universidade de Lisboa.

${ }^{4}$ Assistente da Faculdade de Letras da Universidade de Lisboa.

Investigadores do CEG. Centro de Estudos Geográficos, Universidade de Lisboa, Cidade Universitária, 1699 LISBOA Codex. Tel: (351-1) 79402 18; Fax: (351-1) 79386 90; e-mail: ceg@ mail.telepac.pt
} 
Economic competition does no longer exclusively depend on factor costs, like labour and raw materials, because technology can eliminate the territory disadvantages. Productivity is the crucial element in the competitive capacity of any economy. Productivity, as can easily be proved, is deeply dependent on technological development; which is only possible if there is constant innovation.

This paper starts with a brief discussion on the theoretical issues regarding innovation and territory. In the second section, the innovation resources of the Portuguese economy is analysed in order to understand the innovative strategies of manufacturing firms. Finally, attention is paid to the consequences of innovation policies to the least favoured regions.

\section{1 - INNOVATION, INDUSTRY AND TERRITORY: THEORETICAL ISSUES}

\section{1 - Innovation linear model}

The study of the innovation process has some tradition in Geography, with the first works been developed by HäGERSTRAND (1952). These studies pointed out the space-time diffusion process of innovation and, on a certain degree, they followed a linear and mechanical logic (logistic curve, Monte Carlo model of diffusion simulation,...).

The innovation concept was firstly studied in an isolated way, which means, without detailing its connections with technology, on the one hand, and without the market, on the other hand. The linear innovation model was a paradigm for most of the technology and development policies. The economic theories tended to limit the innovation process to a linear and mechanical relation where, after the Research step (base research or applied research) came the Development step - of products or processes - finally reaching the Diffusion step.

The model places scientific research in a relevant place in the changing technological process because it allows the development of new ideas. These will be worked out till the creation of prototypes, which in case of feasibility, can be industrially made and distributed to the market.

The Research and Development (R\&D) policies oriented by this theoretical model tend to influence two specific areas:

- quantitative and qualitative increase in the R\&D capacity;

- reduction of time between an idea being born and its commercialisation (usually through spatial concentration of infrastructures, equipments, R\&D personnel and enterprises).

The limitations of this innovation model have been pointed out by several authors, who have mainly questioned the unidirectional character of innovation because very often innovations are not the result of a new idea but the resolution of problems with the product itself - market-driven innovation, (MALECKI, 1991 and MASSEY et al., 1992). Simultaneously, the little integration between innovation and society is also criticised. Dosi et al. (1988) analyse the technological paradigms showing the relations between the diagnosed needs, the scientific principles and the materials used in a certain social context. It is also in this sense that FREEMAN (1991) considers crucial the social and institutional change in order to avoid a slow down, or even a separation, between research and the productive system.

\section{2 - From the innovative «milieu» to the innovation networks}

During the eighties, the theoretical perspectives of innovation study began to show other concerns, mainly the role of the territory in the innovation process. According to the neo-classic point of view, space is considered as just an agent with influence in the variation of transport costs, while in the more integrated theoretical perspectives the influence of geography is seen in the ease with which information is exchanged, in the similarity of cultural and even psychological attitudes in the frequency of contacts and cooperation and in the mobility of factors in the local/regional space (CAMAGNI, 1991). 
These orientations can be included in a more global context of territory enhancement in what concerns the social and economical sciences. It is clear the influence of studies on Third Italy paying special attention to authors like Bagnasco, Garofoli and Becattini. The latter was strongly influenced by the concept of «industrial district», which was developed by Alfred Marshall in the beginning of the century. One can also see Stöhr's contributions consolidated on his development model («development from below»), as well as, the influences of the «territorial industrial system» concept developed by Scott in the studies about Los Angeles.

The works developed by GREMI (Groupe de Recherche Européen sur les Milieux Innovateurs), mainly through the first analysis of AYDALOT and KEEBLE (1988), are a reference in the study of innovation.

This theoretical perspective is not only based on the reduction of transaction costs but also on the role of external economies which are considered central elements in the analysis of local productive systems. GREMI has been developing a dynamic theoretical perspective where the local «milieu» holds a generating role in the innovative behaviours. According to CAMAGNI (1991) this role can be defined by the following elements:

- collective learning processes;

- processes to reduce elements of dynamic uncertainty.

The dimension of these territorially integrated new industrial complexes is not, however, very clear, and its articulation with other external relational spaces often collides with its internal logic. The problems that came up have led to a theoretical restructuring in the field of economic geography (BENKO and LIPIETZ, 1992).

Simultaneously with this theoretical evolution in economic geography, the innovation perspective limited to a particular territory has tried to meet new challenges mainly in what concerns the articulation of local spaces with exterior spaces (local or regional) expressed in the creation of trans-regional enterprise networks. CAMAGNI (1991) identifies, as being the strategic elements to the «milieux», the establishment of these innovation networks and cooperation agreements, in order to avoid the negative effects of entropy which is typical of relatively closed systems.

The innovation networks between enterprises should not however, be exclusively understood in a perspective that privileges small and medium enterprises belonging to a particular territory. In fact, the innovation developed by big enterprises - with special importance of transnational firms - is very important, confirming the hypothesis of the weak influence of the territory in the innovation process.

In the most recent analysis, the dichotomy local/international is considered static and reducing. In a cooperation and network logics the local/international relation is essential to understand the competitive strategies of enterprises where the innovation element has an essential role (QUEVIT, 1991). All in all, the innovation process must be studied in a more integrated way, centred in the articulation of local/global scales. Thus, the strictly «closed» analysis of local «milieux» and/or the studies that emphasise the role of transnational enterprises in a «de-territorialized» context should be avoided.

As these territorial issues are central to the economic and social innovation processes, we stress the need to change from a de-territorialised innovation policy to a more integrated and geographical innovation policy in the EU.

\section{2 - GLOBALISATION AND FLEXIBILITY - THE LOCAL IN THE GLOBAL}

The end of the «golden cycle» of world wide economic growth, in the post world-war period and the ensuing recession, marks the change from an «international economy» to a «global economy». The exhaustion of the «fordist» accumulation model and the technological revolution, based on the development of information technologies, has led to the restructuring of the productive system and to important social, cultural, politic-institutional and territorial changes. Production and consumption are organised at a world-wide level and simultaneously 
there has been a huge increase in the extension of the competitive geographical areas (VELTZ, 1993).

The location of production has become more flexible when technological innovations in transport and telecommunications allow to overcome the geographical distance barrier, and therefore, many types of economic activities have become footloose (GASPAR, 1992).

In the major enterprises, different stages of the productive process can have independent locations from each other, taking benefit from the specific advantages of each location (SCOTT, 1988). Thus international trade corresponds to a complex network of firm relations which can take the form of cooperation or subcontracting at world-wide level.

Investment decisions have a wider spatial dimension, and consequently, during the eighties we witnessed a growth in the direct investment made abroad. Never before had these investments been so important and they took the form of fusions, acquisitions, joint-ventures and several forms of strategic alliances among firms (AMIN and SMITH, 1986; AMIN and ROBINS, 1992).

Paradoxically, the globalisation of production creates not only a wider alternative locations span, but also reinforces the selective capacity of the specificity's of each territory in the location decisions of economic activities. We have therefore seen an increasing intense interaction between global competition mechanisms and the diversity of local production conditions (STÖHR, 1990).

As JENSEN-BUTLER (1997) reminds «cities are the most differentiated and complex localities of all, hence the growth of competition between them». In fact, the major cities, after the shock of recession, tried to take advantage of the growing integration of World economy. They have been restructured and, through an extremely competitive process, cities try to achieve a new dimension, changing into structuring nodes of the European and World space, acting as major centres of a complex system of people, goods, services, capitals and information interchange.

The major metropolis stand as «winning regions» at the end of the millennium (BENKO and LIPIETZ, 1992), presenting not only great capacity in innovation processes and diffusion of information, but also comparative advantages due to a good level of infrastructures and equipment, diversity and quality of personal services and business related services, facilities in inter-enterprise relations, plenty of labour force and a vast span of skilled workers and technical staff and the existence of a wide consumer market, in a word, positive externalities. The juxtaposition of these advantages creates synergies which revitalise cities making them attractive both for enterprise settling and residential places (BENKO, 1993).

In the most advanced economies competitiveness does no longer depend on the cost of factors but on the organising capacity. Thus, in the present context, metropolitan regions are those that offer the best flexibility conditions in the short and medium term to enterprises because of their dimension, level of infrastructures and labour skills (VELTZ, 1993).

The new role of cities as leading centres of the World economy has important consequences on the definition of space structures: the sharing of territory in areas of urban influence with different hierarchic levels, like those conceived by Christaller in his central places theory, has been replaced by a structured territory based on a multipolar urban system, defined by multiple hierarchies and connected through information, capitals, people and goods fluxes.

The globalisation of economy and the internationalisation of cities also mean that urban agglomerations with similar positions in the national urban network are facing a challenge imposed by metropolis of other countries. Moreover, the reorganisation of production at a World wide level has induced competitiveness among cities of different hierarchic level that try to attract investments, according to the competitive advantages offered.

In this context, the institutional factors also play an extremely important role in the transformation of the territory dynamics and reinforce competition among places, mainly in the European Union: the implementation of the European Single Market and the Monetary Union; international trade agreements; Community regional development policies; national policies; action of local governments. 
2.1 - Portugal in the international context: innovation and regional competitiveness

It is impossible to quantify the innovation capacity of each territory. However, considering the importance of scientific R\&D in the technological change (OECD, 1986; THWAITES and ALDERMAN, 1994), we can state that the regional and sectorial change of expenditures and employment in R\&D will determine different capacities to generate and use new technologies.

In 1992 the USA had the largest world expenditure in R\&D in absolute figures $(167,010$ million dollars $)^{5}$. Japan was in second place with 73,085.2 million dollars. In Europe, the leaders in R\&D expenditures are Germany, France and the United Kingdom with close to $75 \%$ of the European Union ${ }^{6}$ expenditure. However, one has to keep in mind that these three countries have an R\&D expenditure slightly higher than half of the USA (51\%) and only $12 \%$ above the Japanese expenditure.

Small countries like Greece, Ireland and Portugal have an irrelevant weight in the total of the European research, with an expenditure of 368.6, 486.7 and 678.5 million dollars, respectively.

R\&D expenditures in percentage of the GDP and the personnel working in R\&D per 1000 active people show, once more, that Portugal is lagging behind when compared to the European Union, to other developed Western European countries, to the USA, Canada and to Japan (fig. 1 and 2).

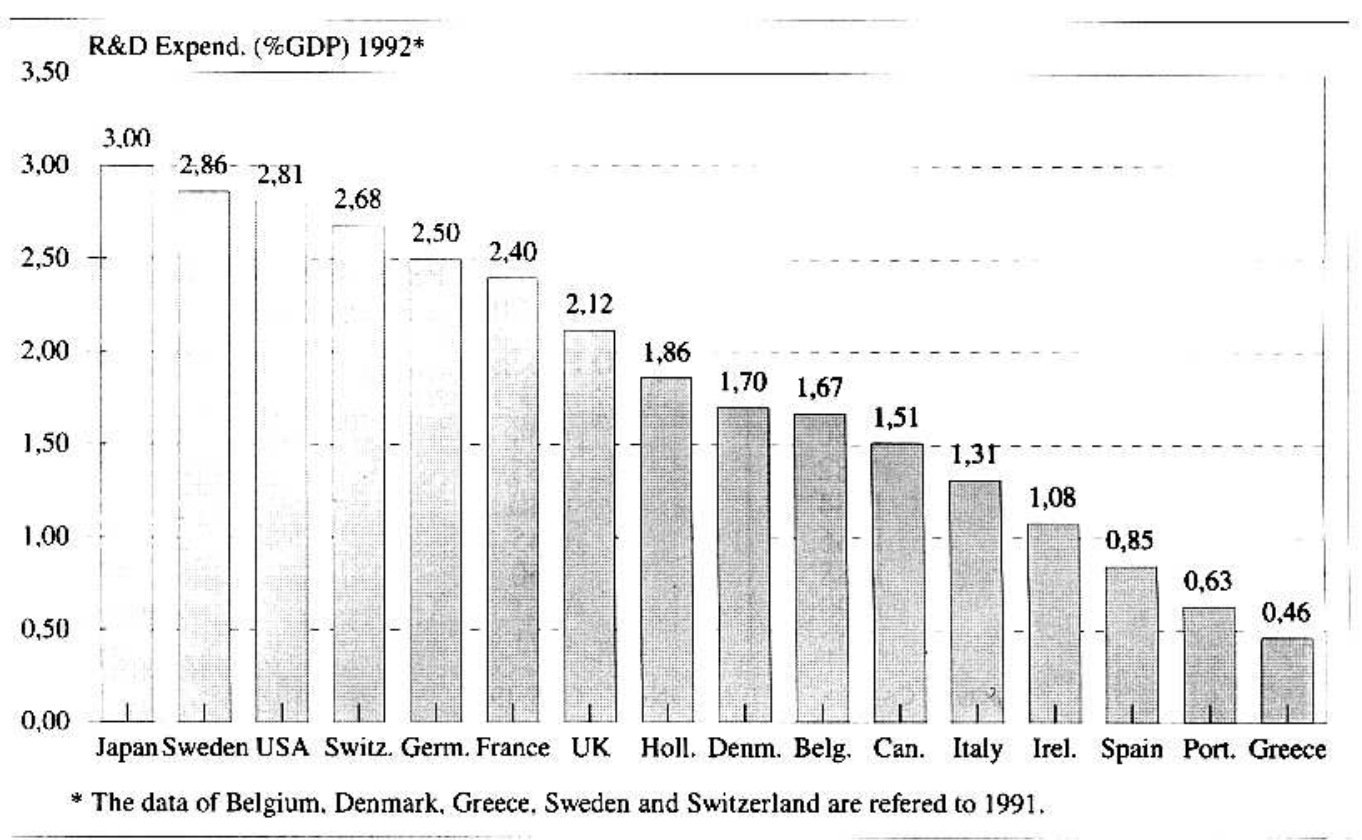

Source: OCDE. 1995: JNICT/GPE. 1995

Figure $1-$ R\&D Expenditure in \% of GDP: Portugal in the International Context. Figura 1 - Despesa Total em I\&D em \% do PIB: Portugal no Contexto Comunitário.

\footnotetext{
${ }^{5}$ In Purchasing Power Standards (PPS).

${ }^{6}$ We consider EUR 12.
} 


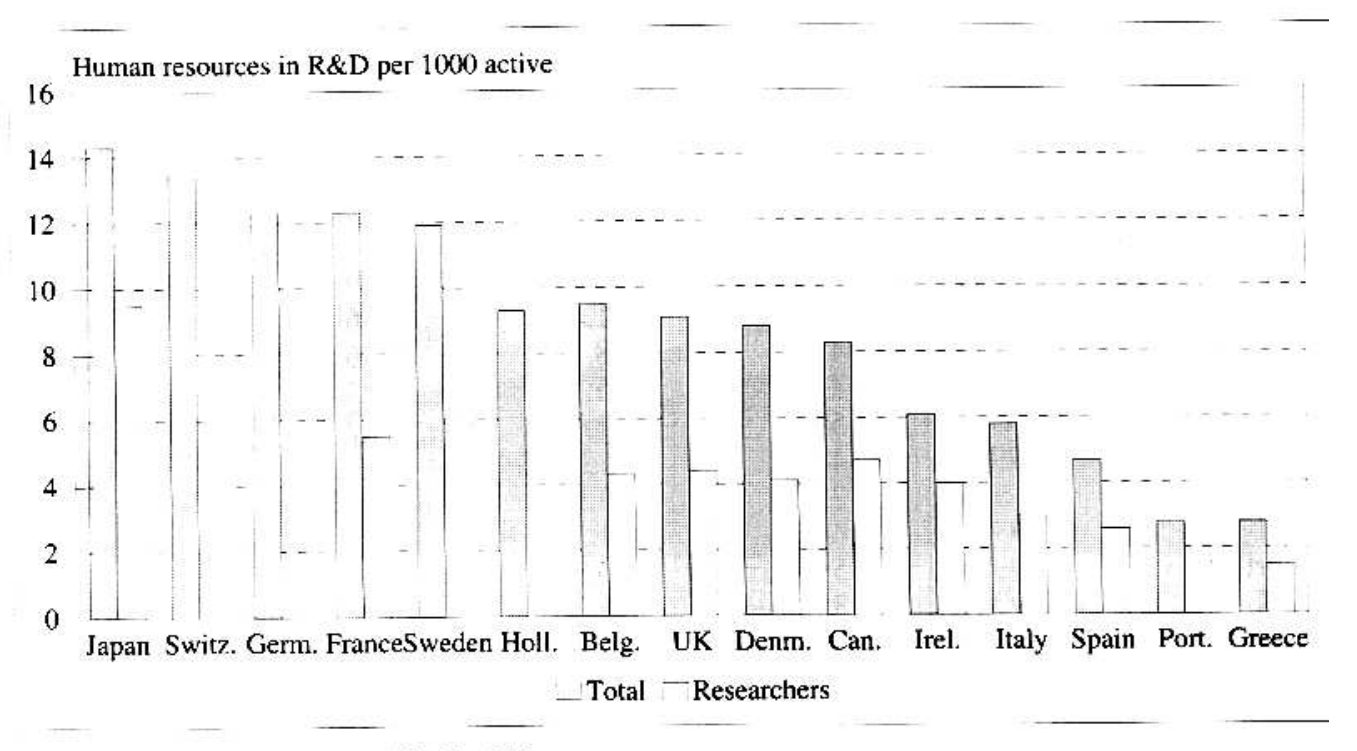

Source: JNICT/GPE, 1995; OCDE, 1995.

Figure 2 - Human Resources in R\&D per 1000 Active People: Portugal in the International Context. Figura 2 - Pessoal em I\&D por Mil Activos: Portugal no Contexto Internacional.

One must also notice that in spite of the considerable increase in the science and technology investment that took place in Portugal during the eighties (table I), the country is still far behind the European average $(0.71 \%$ of GDP while European Union has $2 \%)$.

Table I - Evolution of R\&D Expenditure in \% of GDP in Portugal, 1980-1992 Quadro I - Evolução das Despesas em I\&D em \% do PIB, em Portugal, 1980-1992

\begin{tabular}{|c|c|}
\hline Year & $\begin{array}{c}\text { R\&D Expenditure } \\
\text { in \% of GDP }\end{array}$ \\
\hline 1980 & 0.34 \\
\hline 1982 & 0.35 \\
\hline 1984 & 0.40 \\
\hline 1986 & 0.45 \\
\hline 1988 & 0.50 \\
\hline 1990 & 0.61 \\
\hline 1992 & 0.71 \\
\hline
\end{tabular}

Source: CARAÇA, 1993: 125, JNICT / GPE, 1995.

On the other hand, if the goals in the Regional Development Plan for 1999 are achieved, the financial effort in R\&D will be, by that time, only 1,5\% of the GDP, whereas in the European Union that figure was reached in 1990. This shows that Portugal is nine years behind the EU in terms of innovation expenditures.

Another difference in Portugal when compared to the more developed economies of the European Union, the USA and Japan, is the little importance of enterprises in financing R\&D activities. The State is thus, the main financing source (table II). 
Table II - R\&D Financing Expenditure: Portugal in the International Context Quadro II - Financiamento da Despesa em I\&D: Portugal no Contexto Internacional

\begin{tabular}{|l|c|c|c|c|c|}
\hline Country & & Government & Enterprises & $\begin{array}{c}\text { Other national } \\
\text { sources }\end{array}$ & Foreigner \\
\hline Germany & $(1991)$ & 36.5 & 60.8 & 0.5 & 2.2 \\
\hline Belgium & $(1991)$ & 31.3 & 64.8 & 0.9 & 3.0 \\
\hline Denmark & $(1991)$ & 39.7 & 51.4 & 4.6 & 4.4 \\
\hline Spain & $(1991)$ & 45.7 & 48.1 & 0.6 & 5.6 \\
\hline France & $(1992)$ & 44.3 & 45.7 & 1.3 & 8.7 \\
\hline Greece & $(1991)$ & 57.7 & 21.7 & 0.7 & 19.9 \\
\hline Holland & $(1991)$ & 44.4 & 51.2 & 1.9 & 2.0 \\
\hline Ireland & $(1992)$ & 23.1 & 64.5 & 2.4 & 10.0 \\
\hline Italy & $(1992)$ & 44.7 & 51.5 & - & 3.8 \\
\hline Portugal & $(1992)$ & 59.4 & 20.8 & 5.4 & 5.0 \\
\hline UK & $(1992)$ & 35.4 & 49.7 & 4.1 & 10.9 \\
\hline Sweden & $(1991)$ & 35.3 & 60.5 & 2.7 & 1.5 \\
\hline Switzerland & $(1992)$ & 28.4 & 67.4 & 2.3 & 1.9 \\
\hline Canada & $(1992)$ & 44.1 & 41.0 & 4.6 & 9.9 \\
\hline USA & $(1992)$ & 38.8 & 59.1 & 2.1 & - \\
\hline Japan & $(1992)$ & 19.4 & 71.1 & 9.5 & 0.1 \\
\hline
\end{tabular}

Source: OECD, 1995; JNICT/GPE, 1995.

If one considers the number of researchers in Portugal, their concentration in the public sector, mainly in the universities, is even greater. In 1990 these institutions were responsible for $63.6 \%$ of the total (fig. 3 and 4 ).

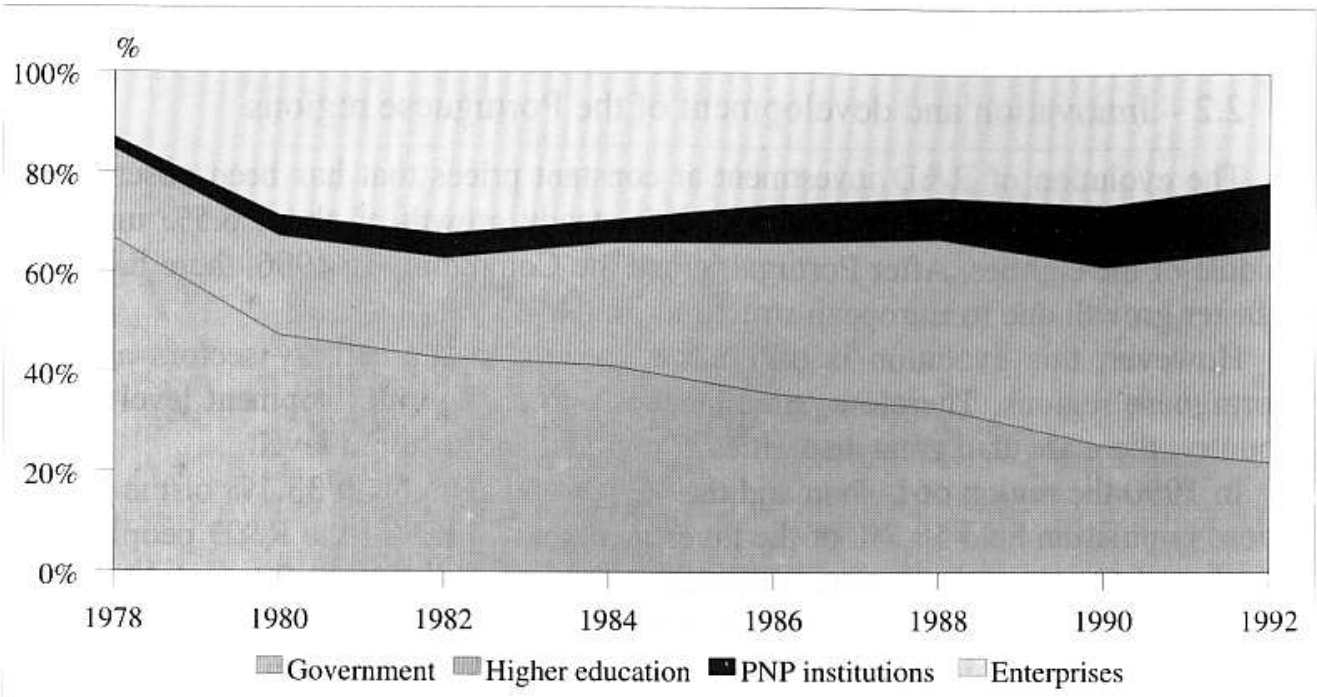

Source: JNICT/SEFOR, 1993; JNICT/GPE, 1995

Figure 3 - R\&D Evolution of Expenditures by Sector in Portugal, 1978-1992.

Figura 3 - Evolução da Despesa em I\&D, por Sector de Execução, em Portugal, 1978-1992. 


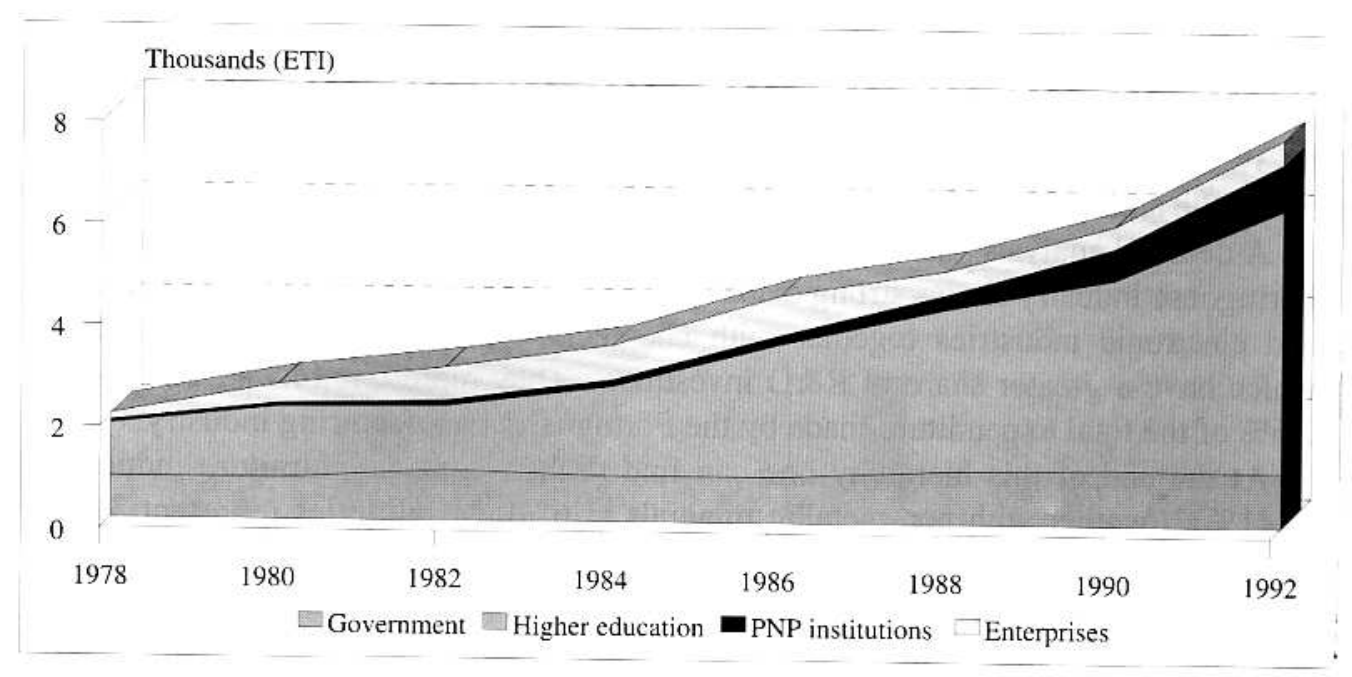

Source: JNICT/SEFOR,1993; JNICT/GPE, 1995

Figure 4 - R\&D Evolution of Human Resources by Sector in Portugal, 1978-1992.

Figura 4 - Evolução dos Recursos Humanos de I\&D, por Sector de Execução, em Portugal, 1978-1992.

This fact is a major blockage to the reduction of the technological development disparity between Portugal and the other European members because the hoor enterprise involvement in R\&D activities makes the commercialisation of innovations and the modernisation of production technologies more difficult.

\section{2 - Innovation and development of the Portuguese regions}

The evolution of R\&D investment at constant prices that has been observed in the last few years points to a more or less steady growth of about $6.5 \%$ until the middle of the eighties. After Portugal joined the Community in 1986, there has been a faster growth due to European structural funds.

However, this evolution is different according to the activity sectors and the Portuguese regions. Therefore, simultaneously to the low development level of the country, there are also great disparities at regional and sectorial level.

In 1990 the region of Lisbon and the Valley of Tagus, with $33.4 \%$ of the Portuguese population held $58.7 \%$ of the investment and $61.8 \%$ of the R\&D people. The North and Centre regions were, respectively, responsible for $21.9 \%$ and $14.3 \%$ of the national expenditure in research. Despite having 14\% of the Portuguese population, the other four regions (Alentejo, Algarve, Azores and Madeira) only had 5.1\% of the expenditure (fig. 5).

If one only considers the $R \& D$ investment made by enterprises, its concentration in the region of Lisbon and Tagus Valley is slightly smaller (50.8\%). The Centre region, and mainly the North region have improved their position absorbing $16.9 \%$ and $25.2 \%$ of the R\&D expenditures.

In spite of the small number of industries that have some R\&D activities, the research developed by these manufacturing industries represents the greatest part of the research effort of the whole productive sector, having $76.9 \%$ of the investment, $83.3 \%$ of the research units and $82.3 \%$ of the human resources from research activities in the areas of science and technology. 
A detailed analysis according to sectors and regions of the innovation potential of Portuguese industry shows strong disparities among sectors and regions. The electric and electronic industries together with chemistry and paper industries are those which have a greater share of R\&D investment. They represent $44.2 \%, 17.7 \%$ and $7.6 \%$ of the total expenditure made by the Portuguese manufacturing industry.

At the end of this hierarchy one can find timber, cork and furniture industries $(0.41 \%)$, together with non-metallic minerals (1.6\%). Metallurgies represent 3.7\%, textiles, clothing and footwear $3.0 \%$, and food processing, beverages and tobacco 5.2\%.

Studying the relationship between the global employment and the number of workers in research activities one can establish an hierarchy of the different sectors in terms of technological development. In table III we can observe the position of chemical industries (CAE 35) with a permilage of workers in research 3.5 higher than the total manufacturing industry. The production of metallic goods, machines and transport material and equipment occupes the second place, with a technology intensity close to three times the average. In the

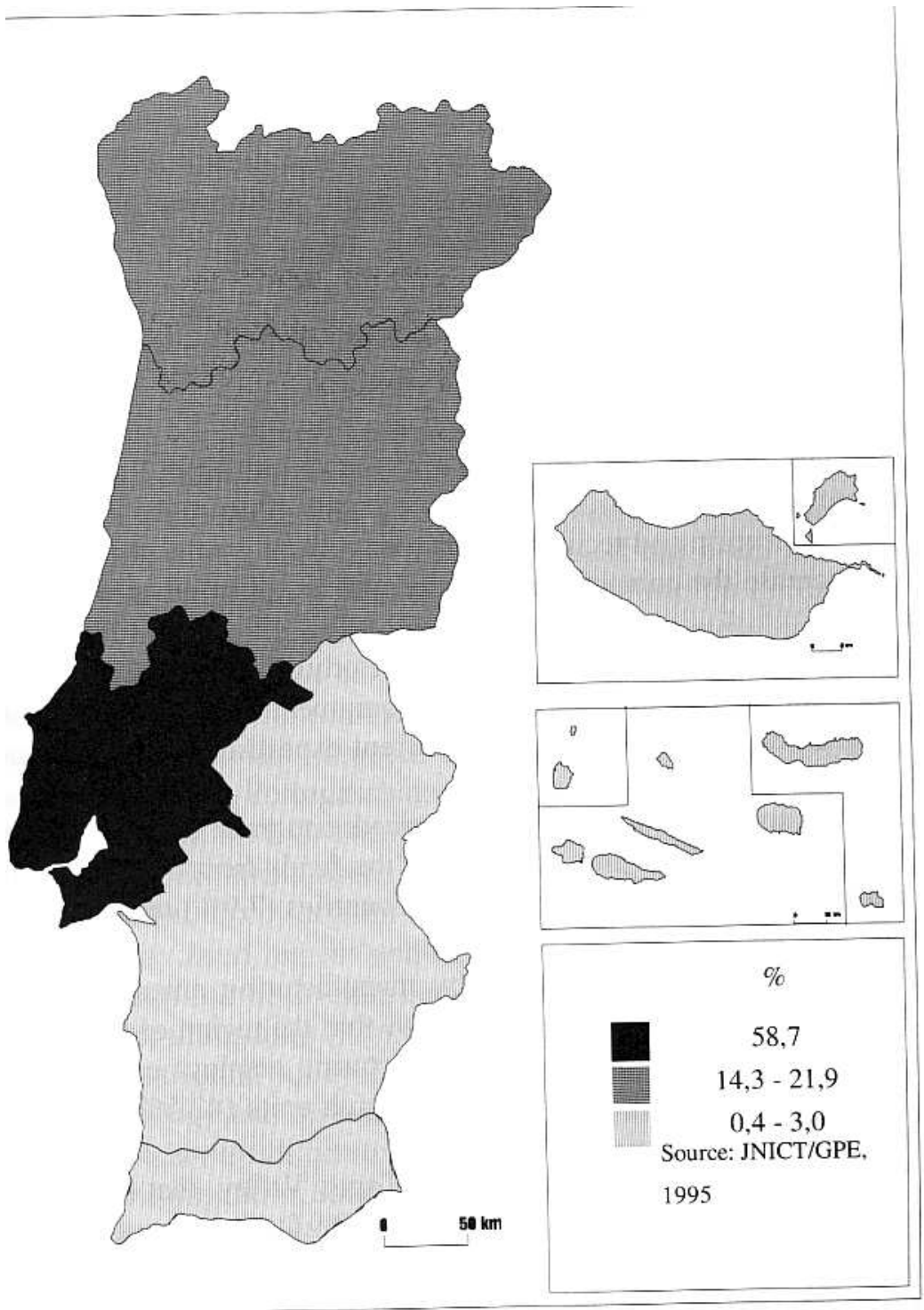

other sectors, only the paper industries, printing and publishing have a share of R\&D human resources higher than the manufacturing industry average. Textiles, clothing and footwear and non-metallic mineral products are those with a smaller innovation potential. 
Figure 5 - R\&D Expenditure by Region, 1992 (NUTE II).

Figura 5 - Distribuição Regional da Despesa em I\&D, por Região, 1992 (NUTE II). 
Table III - R\&D Human Resources per 1000 Active People in Manufacturing Activity in Portugal, 1992

Quadro III - Recursos Humanos de I\&D, por Mil Activos, na Indústria Transformadora em Portugal, 1992

\begin{tabular}{|c|c|}
\hline $\begin{array}{c}\text { Activity } \\
\text { Sectors CAE }\end{array}$ & (R\&D Emp./Total Emp.)x1000 \\
\hline 31 & 0.85 \\
\hline 32 & 0.22 \\
\hline 33 & 0.12 \\
\hline 34 & 2.11 \\
\hline 35 & 5.77 \\
\hline 36 & 0.57 \\
\hline 37 & 0.89 \\
\hline 38 & 4.59 \\
\hline Total & 1.67 \\
\hline
\end{tabular}

Source: JNICT/GPE, 1995; MESS, 1993.

Besides analysing the global financial effort of industries in R\&D activities, it is also important to know the goals of these investments because the higher the share of expenditure in scientific and technical equipment is, the greater the propensity to innovate and increase the competitive capacity will be, or in other words to increase productivity.

In 1992 the manufacturing enterprises in Portugal spent 24.3\% of the global R\&D expenditure on scientific and technical equipment. The other $75.7 \%$ was divided between the employees (46.7\%), other current expenditures (24.7\%) and on land and buildings facilities (7.7 $\%)$.

As far as the source of financing is concerned, one must consider the enterprises' financial resources $(80.7 \%)$. In second place, the funds from the State $(11.3 \%)$ and in third place the funds that come from other countries (7.9\%) mainly through European Structural Funds.

Research and development financed by manufacturing enterprises, besides the sectorial differences already pointed out, shows that the region of Lisbon and Tagus Valley, with 27.2\% of the Portuguese manufacturing employment, has the greatest proportion of R\&D personnel (52.9\%), of research units (42.5\%) and of the R\&D investment (48.3\%).

The North is the region, after Lisbon and Tagus Valley, that shows higher propensity to technological change. It has $35.7 \%$ of R\&D human resources, $33.9 \%$ of research centres and $31.6 \%$ of R\&D expenditure, supported by manufacturing activity. However, keeping in mind that the employment in manufacturing industry in this region is more than half of the country's total, one can easily understand that this region is in an extremely competitive disadvantage when compared to Lisbon, as a result of the profile of industrial specialisation.

Outside the Lisbon and Oporto regions, and if one excludes the Centre, which has $8.4 \%$ of the human resources and $11.0 \%$ of the investment in science and technology, the R\&D activities developed by industrial enterprises are almost non existent.

The sectorial and regional variation of entrepreneurial R\&D in the Portuguese industry is an important indicator of its future economic performance because in the most developed countries, productivity growth is largely due to investment in technology (FONSECA, 1994). Thus, in a context of progressive market internationalisation, the success of industrial enterprises and of the economies of Portuguese regions will depend on their capacity to design and implement competitive strategies, not only profiting from local contexts favourable to innovation, but also from the creation of enterprise networks in a inter-regional basis.

\section{3 - INNOVATION POLICY AND REGIONAL DEVELOPMENT IN THE LEAST FAVOURED REGIONS}


The analysis of the breakdown of the expenditure in $R \& D$ clearly shows a territorial imbalance regarding the Portuguese regions. Another fundamental issue is the low level of the R\&D expenditure in general terms, and more importantly, the hoor level of the enterprise expenditure on R\&D activities. If one bears in mind that an extreme relevant industrial branch such as the textile industry in Portugal, which is rather concentrated in the North coastal strip, did not make a significant effort to innovate, we might think that, in a context of progressive competition in the world economy, this branch will reveal some difficulties in order to maintain its markets.

The innovation policy in the European Union is, to a certain degree, responsible for the innovation policy in Portugal that, in practical terms, was absent before the integration of Portugal in the EU. The design of the innovation policy is typical under the influence of the «Schumpeterian workfarism», in the words of JESSOP (1994), in the sense that it only acts on the supply side. This fact has a tremendous impact in the least favoured regions and in of most the SME. In other words this kind of policy will promote the division between the weaker and the stronger, be they regions, enterprises or individuals (AMIN and THRIFT, 1996).

In Portugal the innovation policy in what concerns the enterprise sector is targeted to the more technology intensive branches often located in the more dynamic urban spaces. On the other hand, creativity and innovation are perceived as a fundamental aspect of the competition between cities and in consequence it has been a key point to the design of the urban economic policies (JENSEN-BUTLER, 1993). The promotion of scientific research and technological innovation comprises the financial assistance to the development of business innovation centres and science and technology parks (VALE, 1994).

The least favoured regions do not have an overall capacity to promote innovation and as a result to overcome this problem they have to import know-how, most of the time in the form of technology, which have lower growth rates than endogenous generated technological change (CASTRO and JENSEN-BUTLER, 1991). Recent R\&D policy should have in its foundations a territorial concern to permit the least favoured regions to apply with success to the available instruments in order to promote innovation.

This particular problem is also present in the theoretical principles of the regional policy in the EU. In fact the logic of these policies is to promote the regional development and the innovation in the territories where some potential, whether in capital, human or natural resources, can be explored in a competitive way. The consequences of these policies will lead to a progressive peripheralization of the least favoured regions and in doing so the ultimate goal of the regional policy - to reduce regional inequalities - can not be achieved.

The changing role of the State in a post-fordist era is, in many ways, responsible for the current situation. As a matter of fact, the nature of the state financial assistance has been changing in the sense of giving up the policies oriented to the demand management and to the planned industrial intervention (AMIN and THRIFT, 1994). These authors synthesise the consequences to the least favoured regions in the following aspects:

- loss of economic vitality and employment due to the reduction of direct state support to the industry;

- assistance only to the economic activities that can be competitive in the global economic space and as a result abandonment of other important sectors to the regional/local economies;

- incapability of the weakest regions to generate growth.

It would be naive to think that it is possible in the current situation to radically change the role of the State, and more so, its policies towards regional development and innovation. Nevertheless, there are some measures that would encourage and reinforce the economic and social cohesion of the least favoured regions. At least it is possible to argue that some of these spaces have genuine local institutions with the capacity to generate and to diffuse innovation. In some areas the universities, local government and $R \& D$ centres amongst other institutions are quite capable of creating the fundamental links with the local economic activity. These 
endogenous institutions should be supported in a more efficient way and their activity should not be ignored in the promotion of the innovation and of the regional development.

The necessary change of the nature of the policies targeted to the innovation and industrial development has to occur. We argue that the design of the different R\&D programmes should reveal more concern for these regions and not only for the massive R\&D infrastructures which have a de-territorialised logic. In the Portuguese case, the initiatives supported by the EU funds and the State focusing those regions and their innovative environment are not enough. The negative consequences are under way because the technological change process is rather slow and not correctly oriented. If we consider that in many of these areas the export base of their economies is vital one must argue if these policies are not jeopardising important local resourses in the sense that endogenous development is genuine and their potentialities are not being promoted in the correct way.

\section{REFERENCES}

AMIN, A.; I. J. SMITH (1986) - The internationalisation of production and its implications for the UK. in A. AmIN; J. B. GODDARD (Eds.). Technological Change, Industrial Restructuring and Regional Development, Allen and Unwin, London.

Amin, A.; K. RoBINS (1992) - Le retour des économies régionales? La géographie mythique de l'accumulation flexible. in G. BENKO; A. LIPIETZ (Eds.). Les Régions Qui Gagnent. Districts et Réseaux: les nouveaux paradigmes de la géographie économique, PUF, Paris.

AmIN, A.; N. THRIFT (1996) - Institutional issues in the European regions: from markets and plans to socioeconomics and powers of association. Economy and Society (forthcoming).

Aydalot, P.; D. KeEBle (1988) (Eds.) - High Technology Industry and Innovative Environments: the European experience. GREMI-Routledge, London.

BenKo, G.; A. LIPIETZ (1992) (Eds) - Les Régions Qui Gagnent. Districts et Réseaux: les nouveaux paradigmes de la géographie économique. PUF, Paris.

BENKo, G. (1993) - Desenvolvimento regional e indústria de alta-tecnologia: um estudo das dinâmicas locativas. Finisterra, Revista Portuguesa de Geografia, 23 (55-56): 73-100.

CAMagnI, R. (1991) (Ed.) - Innovation Networks. Spatial Perspectives. GREMI-Belhaven Press, London.

CARaÇA, J. (1993) - Do Saber ao Fazer: Porquê Organizar Ciência. Gradiva, Lisboa.

Castro, A.; C. Jensen-Butler (1991) - Putting the Social into the Economic. Institut of Political Science, University of Aarhus, Aarhus.

DosI, G. et al. (1988) (Eds.) - Technical Change and Economic Theory. Pinter, London.

FONSECA, M. L. (1994) - Portuguese Labour Market - Challenge and Change. Papers Presented by the Human Geography Unit of the C.E.G. to I.G.U. Regional Conference in Prague. EPRU 41, CEG, Lisboa: 9-22.

FreEman, C. (1991) - The New Techno-Economic Paradigm - the 90s and the beginning of a new century. in Política Científica e Tecnológica para os Anos 90. J.N.I.C.T., Lisboa.

GASPAR, J. (1992) - Societal responses to changes in the production system. Urban Studies, 29 (6): 827$-837$.

HÄgerstRAND, T. (1952) - The Propagation of Innovation Waves. Lund Studies in Geography, Serie B, 4, Lund.

JeNSEN-ButLer, C. (1993) A Theoretical Framework for Analysis of Urban Economic Policy. Institut of Political Science, University of Aarhus, Aarhus.

JENSEN-BUtLER, C. (1997) - Competition between cities, urban success and the role of urban policy: a theorectical framework. in C. JENSEN-BUTLER; A. SHACHAR; J. WEESEP (Eds.). European Cities in Competition, Avebury, Aldershot.

Jessop, B. (1994) - Post-Fordism and the state? in A. AmIN (Ed.). Post-Fordism: a reader, Blackwell, Oxford. 
JNICT/GPE (1995) - Inquérito ao Potencial Científico Nacional - 1992. JNICT/GPE, Lisboa.

JNICT/SEFOR (1993) - Inquérito ao Potencial Científico e Tecnológico Nacional - 1990. JNICT/SEFOR, Lisboa.

MALECKI, E. (1991) - Technology and Economic Development. The Dynamics of Local, Regional and National Change. Longman, Harlow.

MASSEY, D. et al (1992) - High-Tech Fantasies. Science Parks in Society, Science and Space. Routledge, London.

MESS (1993) - Quadros de Pessoal/92. MESS/SICT, Lisboa.

OECD (1986) - R\&D, Invention and Competitiveness. Science and Technology Indicators, 2, OECD, Paris.

OECD (1995) - Principaux Indicateurs de la Science et de la Technologie 1994. OECD, Paris.

QUEVIT, M. (1991) - Innovative environments and local/international linkages in enterprise strategy: a framework for analysis. in R. CAMAGNI (Ed.). Innovation Networks. Spatial Perspectives, GREMI-Belhaven Press, London.

ScotT, A.J. (1988) - Flexible production systems and regional development: the rise of new industrial space in America and Western Europe. International Journal of Urban and Regional Research, 12 (2): 171-186

STÖHR, W.B. (1990) - Global Challenge and Local Response. United Nations University, Mansell, New York.

Thwaites, A.T.; N. Alderman (1994) - Mudança tecnológica e desenvolvimento económico regional. in D. PINDER (Ed.). Europa Ocidental - Desafios e Mudanças, Celta Editora, Oeiras.

VALE, M. (1994) - Electronic industry, regional inequality and innovation policy in Portugal. Cadernos de Geografia, 13: 47-55.

VeltZ, P. (1993) - Logiques d'entreprise et territoires: les nouvelles règles du jeu. in M. SAVY; P. VELTZ (Eds.). Les Nouveaux Espaces de l'Entreprise, Datar, Éditions de l'Aube, Paris. 